\title{
Thatôn (Sudhuim), an Imagined Center
}

SinCE NO KINGDOM or polity independent of Pagán can be found in Lower Burma until, at earliest, the late thirteenth century, this obviously raises serious questions about the existence of its center as well. To be sure, as nucleus of the larger entity, a center can and often does precede it, so conceivably Thatôn could have existed prior to and independent of the evidence for the larger polity. That there was no Rāmañnadesa at the time does not necessarily mean there was no Thatôn also. ${ }^{1}$ What, then, is the evidence regarding Thatôn itself?

Before dealing with the primary evidence, we should consider several things regarding Thatôn. First, the formal Pali name by which Thatôn was known, Sudhamma and variations thereof can suggest a variety of different origins and functions. An early Buddhist text, the Buddhavamsa, records four different Sudhammas, all in India. It is the city in which the Sobhita Buddha was born; it is also his father's name; it is the park in which the Sobhita Buddha was born; and it is a park in Sudhammavati City where Sujāta Buddha held his first assembly of monks. ${ }^{2}$ It was also a name for "Indra's Hall." Although revealing as to the religious symbolism of Sudhamma, none of this tells us much about the historical place in Lower Burma now called Thatôn.

Second, in its domestic context the word Thatôn has a rather revealing etymology. According to Blagden, Thatôn is only the Burmanized form of the place name [Sudhuim], the oldest form of it "I have not, as yet, succeeded in tracing [it] ... in its Mon form," 4 he wrote. He then made a startling remark: "the probability... is that it is not really a Mon word at all, ... [that] the common vernacular name is really derived from the scholarly one [Sudhammavati or Sudhammanagara ... and derived] from Pali, not from Sanskrit." ${ }^{5} \mathrm{Had}$ it been derived from Sanskrit, he wrote, the name would have been ... Sadhaw, just as the Sanskrit word dharma has resulted in the Mon ... dhaw. Therefore, "the actual founders of the town were Buddhists of the Pali-using school, who gave it that name [Sudhuim] and no 
other, in which case the foundation is probably not as old as legendary history makes out. Or else it may have had a much older native name which has now been forgotten, and after the introduction of Pali Buddhism into the Mon country it may have been renamed by its now current, scholarly appellation. But I know of no evidence to show that the place ever had any other name than its present one. ..."6

This conjecture is rather astounding: the name of the quintessential city of Mon origins in Burma is not even Mon and ultimately derives from Pali! Indeed, Halliday does not include the word in his dictionary while Shorto includes it with a query, and categorizes it as Middle, not Old Mon. ${ }^{7}$ That it is written in Middle Mon is consistent with the evidence regarding the chronology of other place names in Lower Burma located near Thatôn, where all dated, urban place names written in Mon occur after the midfifteenth century.

Blagden's analysis suggests, furthermore, that the vernacular form Thatôn came only after its former Pali name was coined, so that the "vernacular name is really derived from the scholarly one." ${ }^{8}$ It was not, as in many other place names in Southeast Asia, a local one that was only subsequently honored with Sanskrit and Pali suffixes. Thus, it is neither like Muttamanagara, clearly taken from the native Muttama to which was attached the Sanskrit nagara, nor like Hamsavatì, a totally unconnected scholarly name for the local name Pegu.

But as this chapter is less a search for the etymology of the word and more for the city of Thatôn as a historical center of the Mon prior to the development of Pagán, we will not pursue the present topic further, except to reiterate that the origins of the word lay in its formal Pali name Sudhamma and its variations, which must have preceded its local form, Sudhuim, which did not appear in original domestic epigraphy until the last quarter of the fifteenth century, and whose local pronunciation (Thatôn) is Burmese, not Mon.

\section{Thatôn in Archaeology}

The archaeological issues concerning the city of Thatôn center on its identity, chronology, and ethnicity. There is an excavated urban site within today's Thatôn that archaeologists have assumed to be the Thatôn in question. ${ }^{9}$ Although not unreasonable, there is no scientific, epigraphic, or other literary evidence that this particular site was the Thatôn of Burma's legend and history. And without such evidence, what stands there today could have been any old city. Indeed, the debate, such as it is, is reminiscent of the "search for Troy" in classical western archaeology, where at one time nearly every new site discovered near the Bosporus was considered to be 
Troy. Most certainly, the name Thatôn was given to the site not because of archaeological or epigraphic evidence contemporary to or found at the site, but because of local tradition and the prevailing assumptions of the Mon Paradigm.

At this site virtually all that might point to a polity of sorts is a partially excavated structure that might be a palace and approximately half of the rectangular city walls. But these walls are built on a plan that is, according to the late, distinguished archaeologist of Burma, U Aung Thaw, "like the more modern cities of Amarapura and Mandalay." 10 I am not implying here that Thatôn was necessarily as recent as Amarapura or Mandalay, but rather that its chronology prior to the fifteenth century is highly uncertain. The following quote, from the Burma Gazetteer: Thaton District, contains one of the earliest reports on the site.

The ground plan of the outer rampart is a square or oblong within which is an open space of about 150 feet, and then a second but lower wall, rampart, or moat. The east and west inner walls are each 7,700 feet long while those on the north and south are about 4,000 feet each, enclosing a space of about 700 acres. The angles, however, are not exact right angles. The centre of the city is the fortified royal citadel measuring from the north to south 1,080 feet, and east to west 1,150 feet. This was for the defence of the palace, the 'throne room' being, as is now the case at the Burmese capital, nearly the centre point of the city. There are two gates or spaces for entrance in the northern and southern faces of the rampart, but it is impossible to say how many on the eastern and western. Of the citadel no remains exist save those of a small pagoda at one corner, the shape of which is not discernible. The walls are of earth and in some places much worn away, but some places appear to have been faced with rough stones." 11

The remains of Thatôn, therefore, do not resemble the cities of the preclassical period in Southeast Asia to which it was said to belong-such as Dhanyawaddy and Vesāli in Arakan, Śrī Kṣetra, Mongmao, Beikthano, Wati, and numerous other Pyū cities in central Burma, early Sukhodaya in Thailand and Angkor Borei in Cambodia. All or most of these cities have more or less rounded corners or circular designs in general, sometimes with two or more concentric moats and walls surrounding them. Instead, in its largely rectangular plan Thatôn resembles the cities that arose after Pagán. ${ }^{12}$

And even if a case can be made that the site under discussion is older, the evidence points to its belonging to the Pyū culture of Upper Burma, for distinctively Pyū fingermarked bricks have been used at Thatôn and nearby sites such as Kyaikkatha, Sanpannagon, and Tavoy. Beads and pot- 
tery similar to those at Beikthano have also been found..$^{13}$ Indeed, I would not be surprised if the origins of the name Sudhamanagara actually went back to the Pyū rather than the Mon, an issue addressed below.

Chronologically the site also poses some problems. The excavations, conducted between 1975 and 1977, did not produce any radiocarbon or other scientific dates, and by now much of the site has probably been contaminated. ${ }^{14}$ Until excavations of uncontaminated sections are conducted properly, there is no way to know whether the site is post fifteenth century, as the etymology of its name suggests, or belongs to an earlier period. Certainly there is no evidence that this particular site was the city said to have been conquered by Aniruddha in 1057-even assuming that event was historical, which is now in doubt as we shall see in the next two chapters.

Even if uncontaminated material can be found and successfully dated prior to Pagán, that the city was "Mon" will still be conjectural, for any presumed relationship between the Mon and any particular site would be difficult to document without linguistic evidence. To be sure, ample Indic and presumably local cultural remains excavated at or near this site suggest settled occupation at an early period. Bas reliefs, laterite statues, ablution stones, grooved laterite drains, laterite finials, animal figures of lions, tigers, and elephants, altar stands, a whole terraced stupa made of laterite, and even a laterite wall presumably of a fort with sculptured panels have been unearthed in the general vicinity. ${ }^{15}$ There is also evidence of bronze Buddha images, Śiva, Pārvatī, Nandi, Viṣnu, dvārapālas (guardian deities), terracotta plaques, along with evidence of Theravāda Buddhist texts such as the Vessantara and other popular Jätakas as well as other items related to this school of thought. ${ }^{16}$

Yet even though not a single one of these remains has been dated scientifically or by epigraphy, a necessary connection between the remains and Mon speakers has always been assumed because of the Mon Paradigm. But even supposing that a stylistic case can be made that artifacts found at the site called Thatôn "look like" those of Dvāravatī or Haripuñjaya—the only Mon standards available during the general period in question-there still is no evidence that Mon speakers inhabited the site at the same time. In fact, as noted in earlier chapters, Winga, a site celebrated as Mon and said to have been contemporary with or earlier than the mythical Rāmañnadesa, cannot be dated by epigraphy earlier than $1479,{ }^{17}$ a date confirmed by TL results. That Thatôn was later inhabited by Mon speakers, of course, is not being disputed.

No archaeological, epigraphic, or other scientific evidence demonstrates that the excavated site called Thatôn is the Thatôn of legend, that it is older than Pagán, or that it was inhabited by Mon speakers during the first millennium. Instead, because the Mon Paradigm asserted that Thatôn 
was already the center of a highly developed Theravāda Buddhist kingdom inhabited by Mon speakers prior to the rise and development of the Pagán kingdom, researchers automatically assumed that everything found there had to have been Mon. Premise, once again, had become proof.

\section{Sudhuim in Domestic Epigraphy}

The only kind of evidence that can unequivocally determine whether a certain ethnolinguistic group produced a particular artifact, built and occupied a particular place, or was present during a particular period of time is securely dated epigraphy found at the site written in the language known to have been spoken by that same group. In this case, one needs at least one original, in situ epigraph written in Old Mon, unambiguously dated to sometime prior to the mid-eleventh century and preferably corroborated by radiocarbon or other scientifically derived chronology. But not one of the six original stone inscriptions in the Old Mon language written in the Pagán script, found at or near Thatôn itself, or any of the eight more found in all of Lower Burma, erected prior to the late fifteenth-century Kalyani Inscriptions, ever once mentioned Sudhuim. ${ }^{18}$ Nor is the word found in any original Old Burmese inscription of Pagán from among the approximately 700 stones that remain from several centuries of Upper Burma rule of most of the country. ${ }^{19}$

Yet, as noted in Chapter Three, under King Narapatisithu's reign (1173-1210) the urban sites of Tenasserim, Tavoy, and Muttama were under Pagán control, ${ }^{20}$ while earlier, during Aniruddha and Kyanzittha's reigns, evidence documents Pagán's conquests into at least two places beyond Mergui. Since all these towns were located much farther south than the site alleged to have been ancient Thatôn, it, too, should have been mentioned, as it lay directly on the land route to Tenasserim. Subsequently, in the twelfth and thirteenth centuries, kings and queens of Pagán made donations in Takun, Tala, Pegu, and Mergui, but not at Thatôn. ${ }^{21}$

When Mingaung I, a contemporary of King Yazadarit of Pegu, listed some Lower Burma cities that he claimed to control or contest, such as Tala and Takun in the Delta, not once did he mention Thatôn. ${ }^{22}$ When Queen Shin Saw Bu, the second of only two women sovereigns of Burma, set up several donative inscriptions in Lower Burma, one of the legible ones records the building of a temple at or near Muttama, just south of Thatôn, but fails to mention that city at all. ${ }^{23}$ At the height of the Ava period, another able king, Narapati I, would claim on an inscription of 1448 that he controlled centers in western and Lower Burma such as Arakan, Sittwe (also in Arakan), Bassein, and Myaungmya in the Delta. Again, Thatôn was not on the list. ${ }^{24}$ In short, even during the period when Pegu had emerged 
as the center of Mon power in Lower Burma, Thatôn was still not mentioned in either Mon or Burmese epigraphy.

Thatôn finally appears, as Sudhuim, for the first time in original domestic Middle Mon epigraphy in 1479, on King Dhammazedi's Kalyani Inscriptions, ${ }^{25}$ where it was connected to the famous Manuha of the chronicles whose formal title is given as Sūriyakumā. Later in the same inscriptions, the city appears again among a long list of sima (ordination halls) said to have existed throughout Dhammazedi's kingdom during his reign. It was called the Gavampati sima of Sudhuim. ${ }^{26}$

A decade later, in 1486, Sudhuim appears again as Sudhammapura in three Mon inscriptions. ${ }^{27}$ In them, the famous Buddhist arahant Gavampati is said to have been reborn as a disciple of the Buddha, who goes to Sudhuim to preach Buddhism where Sìrimāsoka, said to have been a kinsman of his in a former existence, ruled. Thereupon, Sïrimāsoka requested that the Buddha himself visit the city, which he did, making Sudhuim a "Buddha-visited-city," an honor of utmost importance to Theravāda Buddhists.

This data led Shorto, the eminent Mon scholar, to conclude, in a seminal article called "The Gavampati Tradition of Burma,"28 that Gavampati was the patron of the Mon and the tutelary deity of Thatôn. ${ }^{29}$ That in itself creates no problems. However, Shorto then projected this "Gavampati tradition" that he himself had constructed backward to eleventh-century Pagán. He reasoned that because Gavampati is mentioned in an eleventhcentury Old Mon inscription of King Kyanzittha in a context of city-building, the Gavampati tradition, and by implication the city of Thatôn, must have existed in the eleventh century as well. ${ }^{30}$

Yet the inscription that Shorto cited as evidence has only the following to say on the subject:

Thereupon the Lord Buddha spake . . . to the Lord Ānan thus: “ Ānan, hereafter a sage named Bisnū, great in supernatural power, great in glory, possessing the five transcendental faculties, together with my son Gawampati, and King In, and Bissukarmmadewaput, and Katakarmmanāgarāja, shall build a city called Sisīt [Śrī Kṣetra]. After that, the sage Bisnū . . . departing from thence, shall go up to Brahmalok; (and) departing from Brahmalok, shall come to be in the city of Arimaddanapūr, (and) shall bear the name of King Śrī Tribhuwanādityadhammarāja, (and) shall uphold my religion."

At that time the Lord Gawampati, hearing the explanation of the Lord Buddha ... questioned (him) thus: “. . . did my lord truly say that hereafter a sage named Bisnū together with me should build the city of Sisīt?" "Truly, Gawampati, thus (it is). . . Therefore, Gawampati, go thou to King In, (and) speak thou thus: '. . . the Sage named Bisnū, who is great in supernatural power (and) glory, together with me shall build the city of Sisit. . . . After the 
sage Bisnū has built the city of Sisit, he shall depart from thence (and) in the city of Arimaddanapūr he shall become King [Kyanzittha].'”31

Neither the Mon people, nor Thatôn, nor Gavampati's relations with either, is mentioned or implied. Only two cities are recalled: Śrī Kṣetra and Arimaddanapūr (Pagán)_-and those in an archaeologically and historically correct sequence-so that the important links being made are between Gavampati and Śrī Kṣetra on the one hand, and King Kyanzittha and Pagán on the other. Thatôn was never a part of Kyanzittha's legitimation scheme. Thus the earliest evidence we have regarding the Gavampati tradition is found in and concerned with Upper, not Lower Burma, and is concerned with the "establishment" of Śrī Kṣetra and Pagán, the "quintessential" capitals of the Pyū and Burmese speakers respectively, not with Thatôn and Mon speakers.

The earliest epigraphic evidence, suggests, therefore, that Gavampati is far more likely to have originally been the patron of the Pyū and Burmese speakers than of the Mon, and more likely the tutelary deity of Śrī Kṣetra and Pagán, not Thatôn. Had Thatôn and the Mon been as important in the eleventh century, either symbolically or historically as Shorto claimed, and if King Kyanzittha-said to be the patron par excellence of Mon language and culture-was indeed celebrating the genealogy of great Buddhist cities of Burma such as Śrī Kṣetra and Pagán, why were Thatôn and the Mon never mentioned?

In the Kalyani Inscriptions Sīrimāsoka, Gavamipati’s kinsman, was said to have been the reigning king at Thatôn when Soṇa and Uttara arrived nearby with the Holy Scriptures. This is well after the Buddha's parinibbānna, ${ }^{32}$ not during his lifetime, as the 1486 inscription used by Shorto states. On another occasion during the Buddha's lifetime, Gavampati is again present, operating as liaison between the reigns of Sirimāsoka at the beginning of the dynasty and Sūriyakumā at the end when Lower Burma was said to have been Suvaṇnabhūmi, representing respectively, the beginning and end of Thatôn's dynastic list. In yet another existence, Gavampati is hatched from one of two eggs found in the vicinity of Zingyaik hill in Lower Burma as Candakummā; from the other egg is hatched Sūriyakuma $\bar{a}^{33}$ — the infamous Manuha - the two representing the Moon and Sun respectively. So this story "makes" Gavampati also a contemporary of Sūriyakumā. In King Dhammazedi's time, Gavamipati was a Mahāthera who preached at Thatôn, and in the eighteenth century, he was reborn as Wimala, one of two brothers who founded Pegu. In the context of reincarnation (or more precisely, avatarship), Gavampati's mythology is, of course, indifferent to historical chronology; he is present everywhere at any time, as different beings performing different functions. 
This conflation of time, events, places, and individuals was an ahistorical scheme used by Kyanzittha and later Dhammazedi for legitimation purposes. It was also, unfortunately, one to which Shorto succumbed. He had conflated time, events, places, and individuals by placing the Gavampati "tradition of the Mon" in King Kyanzittha's eleventh-century Pagán when his sources for that tradition were clearly fifteenth-century Pegu and later. This was the result, essentially, of a modern synchronous approach to history within the context of an assumed Lower Burma antiquity. Apparently the use of "messianic time" is not a characteristic only of "traditional" societies.

Although one may concede that part of Shorto's argument can be supported by the texts of the 1486 inscriptions, as well as an eighteenth-century manuscript that he translated called "Gavampati," ${ }^{34}$ neither Gavampati's role as tutelary deity of Thatôn nor as patron of the Mon can be found in the eleventh-century inscription of King Kyanzittha he cited. That information can be found only in the fifteenth and eighteenth-century texts noted, information that was then anachronistically projected backwards.

Exciting and thought provoking though his thesis may be, Shorto's mistake lay in accepting the Mon Paradigm's assumption that everything Mon and Lower Burma was earlier and everything Burman and Upper Burma was later. ${ }^{35}$ In circular fashion, this projection backwards of what was actually a much later Mon tradition not only helped cement the notion of an earlier Thatôn in Lower Burma-and therefore a Mon civilization alsobut made it appear as if Pagán had borrowed components of its belief system from the Mon of Lower Burma when it was clearly the other way around. In fact, because the Gavampati tradition appears in the original evidence at Pagán in the eleventh century, four hundred years earlier than it does in Lower Burma, the traditions surrounding Gavampati most likely went from Upper to Lower Burma, a pattern consistent with all the other evidence we have on the chronology and direction of state development in the country.

\section{THE RAKṢAPURA ISSUE}

Because the overwhelming body of evidence fails to mention Sudhuim earlier than Dhammazedi's Kalyani Inscriptions, Luce was obviously compelled to find a substitute for it in "original" epigraphy, preferably one dated prior to Aniruddha's alleged conquest. This resulted in a most bizarre thesis, one that I call here the Rakșapura Issue.

In the 1930s the archaeological service found two inscriptions at Thatôn written in Pali and Mon that are now known as the Trāp and Paṇdit Inscriptions. They were not found in situ; that is, they were not permanently attached to the place where they are now located-the Shwézayan temple compound at Thatôn-and therefore, their provenance is 
unknown. Also, it is not entirely clear who erected them. Most serious, we do not know when these inscriptions were erected; there is no legible date on either.

Despite this, Luce dated them anyway, to "c. 1050," so that they just barely preceded Aniruddha's alleged conquest of Thatôn by seven years. As he put it: "they [the inscriptions] must precede, and very shortly precede, Aniruddha's capture of the city." ${ }^{36} \mathrm{He}$ then took an isolated word from the two inscriptions-Raksapura (city of demons) —with no coherent narrative attached to it, and concluded that this Raksapura was really a reference to Thatôn. And presto! not only was the existence of Thatôn "confirmed" in original, eleventh-century Old Mon epigraphy, but the inscriptions conveniently "preceded" the alleged conquest of Thatôn by seven years. The entire analysis was patently self-fulfilling.

No reasoning was provided for these assertions, particularly how the term Rakșapura might have been connected historically, linguistically, or palaeographically to the words Thatôn or Sudhuim. Luce then contradicted himself almost immediately by stating that these rakșas (demons) were actually Malayan "Vikings." 37 It is not clear to me how one arrives at Thatôn and the Mon from Rakṣapura and the Malays; it was never explained. Besides, if we were to pursue the logic of Luce's own argument, Rakṣapura should have been a Malay, not a Mon city, and its king, a Malay, not a Mon. Apart from this illogic, the fact remains that Thatôn (Sudhuim) is not mentioned on the Trap and Pandit Inscriptions in any way, shape, or form $!^{38}$

To be sure, there are numerous late Mon chronicles and legendary accounts that link raksa stories to Muttama and Thatôn, as we have seen in Dhammazedi's use of the Dipavamsa story regarding the ogress. ${ }^{39}$ But this sort of tale is hardly evidence of Thatôn's eleventh-century historical existence or that the city was called Rakșapura. Besides, such stories of demons are not unique to the Mon-they are also found among the Arakanese and Burmese-and were obviously an allegory of Buddhism's ability to conquer metaphorical demonhood, a literary device for validating conversion to the "true faith." In many of these stories, those not yet converted to Buddhism have usually been described as ogres or uncivilized people who worshiped "false gods" or professed "false doctrines" (such as the Aris of Pagán) until they saw the light.

The stories may also have been allegories of chaotic events of the late thirteenth and early fourteenth centuries in coastal Southeast Asia. Both the Javanese kingdom of Majapahit and a resurgent Śrī Vijaya in a new Malacca $^{40}$ had become important; along with the rise of Ayudhyā and its interests regarding the Malay Peninsula. ${ }^{41}$ The Javanese influence particularly had gained momentum not only in the Straits of Malacca but in the 
northern parts of the Malay Peninsular near the Isthmus of Kra and into Tenasserim. That they may have come in contact with Yazadarit's authority in Tenasserim during that time, when it was under Pegu's control or influence, is attested by one of the earliest Mon chronicles, which mentions "Java Kalas" (literally "Java Indians") wreaking havoc in the region around the same time. ${ }^{42}$

In other words, had these accounts been historical, the term Raksapura was most likely a reference to some other city, in the sense that Yazadarit drove these rakșas or "demons" out of his kingdom back to Rakșapura where they belonged. If not the Javanese, the rakșa may have been references to the Malays, or T'ais from Ayudhyā, with whom Yazadarit's dynasty had obvious contact. The reference also could have been to the inhabitants of nearby Ogre Island (Bilu Kyun in Burmese) in the Gulf of Muttama near Thatôn. ${ }^{43}$

Besides, these stories about demons actually convey exactly the opposite meaning to the one Luce wanted to suggest. If allegorical, the raksas represent barbarism prior to the civilizing influence of Buddhism, and if historical, they represent the kingdom's enemies, so that Raksapura had to be a name given to some other, demonized place. How, therefore, can one assign the term to Thatôn, when the rakșas were either (allegorically) its antagonistic elements or (historically) its actual enemies? Common sense alone suggests that no Buddhist king would have called his own beloved, holy, and Buddha-prophesied city the "City of Demons" anyway. After all, the Pali term for Thatôn, Sudhamma, stemmed from revered, not disparaged, Buddhist traditions.

One can hardly consider this kind of illogical argument as proof for the existence and chronology of Thatôn. Indeed, to have based such an important component of the Mon Paradigm - the identification and date of the center of Rāmaññadesa-on such flimsy data and analysis, on a single term whose meaning was just the opposite of the attributed, desired purpose, reveals a consistent pattern of forcing data into a preconceived mold no matter how illogical or weak.

\section{Thatôn in External Sources}

None of the contemporary or near-contemporary epigraphy from South Asia mentions Thatôn or its Pali equivalents. The 1025 inscription of Rājendra Coḷa I of South India that celebrated his raid against Śrī Vijaya and other parts of Southeast Asia did not mention Thatôn, although thirteen other urban areas were included as his raid went along the Tenasserim coast, south of where Thatôn was supposed to have been located. ${ }^{44}$ Had the city been a vibrant and powerful Theravāda Buddhist center in the vicinity, 
why was it not even mentioned? More than a century later, in 1165, the Devanagala Rock Inscription that Parākramabāhu I had erected to commemorate a raid conducted in precisely the area of Lower Burma alleged to be Rāmaññadesa did not mention Thatôn, even though Kusumìya, the Pali term for Pusim or Bassein, was included as one of the Lower Burma delta towns raided. ${ }^{45}$

Some of the best, sometimes the only, evidence we have for early Southeast Asia are the Chinese sources: not a single official one mentioned Thatôn. Even more compelling-because Thatôn was alleged to have been a great Buddhist center-not a single Chinese Buddhist pilgrim among the dozens who visited Southeast Asia and India mentioned Thatôn either. Neither Hsüan-tsang nor I-tsing (I-Ching), two of the most prolific, included the city in their accounts, although they described in often precise detail, virtually every other Buddhist center in Southeast Asia in the seventh century. ${ }^{46}$

In short, not a single pertinent contemporary or near-contemporary source-internal or external, in Burmese, Mon, Pali, Tamil, Sinhalese, or Chinese-during the entire first millennium and well into the fifteenth century mentions the city. Is this not reason enough to reexamine the theory that a pre-Pagán Thatôn existed in Lower Burma and that it was the center of a flourishing Mon Theravāda Buddhist kingdom called Rāmaññadesa, for which no evidence exists either?

\section{Thatôn in Fifteenth- and Sixteenth-Century Sources}

The search for Thatôn next led me to later domestic literary sources. Several did mention what could be construed as Sudhuim, but since none of these texts is original and contemporary, and their earliest extant copies date to the late eighteenth century, none can be considered a source able to verify the existence of Thatôn earlier than the period in which they were created, and even that assumes that their copiers were faithful to the originals. But these sources are important, nevertheless, for showing how late the mythology of Thatôn appears, how unimportant it was to the Burma Mon earlier, and how it is more closely linked to the Mon of Thailand than to those of Lower Burma.

As noted in earlier chapters, the Zambu Kungya Po Yaza Mu Haung was reportedly written during the First Ava Dynasty (1364-1527) by Wun Zin Min Yaza, an advisor to three successive Ava kings. Although the work itself was said to have been written during Mingaung I's reign (1401-1423), ${ }^{47}$ the only extant palm-leaf copy that I have found (on microfilm) is dated to $1825 .^{48}$ It is too late to be considered an original, contemporary source, but it does have the markings of an early Ava source and contains information 
found in only one other Ava chronicle, the Zatatawpon Yazawin, to be discussed more fully in Chapter Six. The Zambu is one of the earliest to mention Thatôn, but in the context of Aniruddha's religious reform rather than a conquest. This raises numerous questions about the historical and religious circumstances in which the Zambu and other Burma chronicles were written, issues well beyond the scope of this book.

Close to the Zambu in time is the Cāmadevivamsa, a Northern Thai chronicle which Thai scholars claim was written sometime between 1410 and 1417 by a monk named Bodhiramsi. ${ }^{49}$ It is a "history" of the kingdom of Haripuñjaya, perhaps a Mon polity, located in what is now Thailand. It also mentions a Sudhamma, that in context may refer to Lower Burma. ${ }^{50}$ It states:

At that time [the early tenth century] the people of Haripunjaya suffered from a widespread cholera epidemic. Many died of the disease. Those who lived in houses with a cholera victim contracted the disease in such increasing numbers that none of them survived. At last, even those people who touched an object in a cholera-infected house became inflicted with the disease and died.

The people suffering with cholera were abandoned; those who survived destroyed their houses and fled for safety. Therefore, the remaining population of Haripunjaya, in order to save their own lives, fled to a city named Sudhamma and settled there. The city of Haripunjaya consequently fell into decline, ... and was abandoned ... altogether.

The king of Pukam, observing the masses of weak and starving people, was moved to pity and out of his compassion restored the city of Sudhamma for them to occupy.

Unable to bear their suffering any longer, the people of Haripuñaya left Sudhamma ... and went to Hamsavatī . . . where they continued to live. At that time the king of Hamsavatī, seeing the (needs of the) people of Haripuñjaya, out of his compassion and sense of justice . . gave them many necessities, including clothing, jewelry, paddy, rice, various salty and sour foods, and dwelling places.

The inhabitants of Haripuñaya and of Hamsavatī [note: not Sudhamma!] came to know and love each other. Even their languages were the same. Because no difference was found in their speech, they were able to understand each other easily. After six years, the cholera epidemic subsided. When the disease was brought under control, those who wanted to return to Haripunjaya departed and dwelt again in the city.

Those who did not want to return or who were too old or who had married the sons or daughters [of the local people] remained at Hamsavatī. . . With the return of so many of its former inhabitants, Haripuñjaya was restored 
to its former glory. The people of Hamsavatī, who still loved their friends and relatives in Haripuñjaya often visited them, bearing many letters. ${ }^{51}$

There are several intriguing pieces of information in this quote. "The king of Pukam" suggests that this Sudhamma might have been in Burma, although a Sudhamma within the kingdom of Haripuñaya is also mentioned.$^{52}$ Chronologically as well, it is possible that someone from the Pagán Dynasty was involved, since the recent radiocarbon tests which date the foundations of Pagán's city walls to the late tenth century and the Câmadevivamsa's reference to the epidemic during the reign of one Kamala, around 921 AD are close enough to consider seriously. Moreover, Sudhamma's restoration by the king of Pukam suggests the city's prior existence, although how much earlier is difficult to tell, as is the ethnolinguistic group inhabiting it at the time.

The problems, however, are more serious. First, although the language of Hamsavatì's inhabitants was said to have been the same as that of the refugees from Haripuñjaya (assumed to be Mon), nothing is said of the language of Sudhamma, the city at issue, so there is no proof that the language of its inhabitants, presumably Mon, was the same as that of Haripuñjaya. Indeed, that the narrative moves from Sudhamma to Hamsavatī without any explanation, especially when "the king of Pukam" was said to be so compassionate, suggests either some confusion or a combination of two different stories.

Second, the narrative that included Sudhamma in this text may have been a later addition to an older section, ${ }^{53}$ since the alleged epidemic, directly related to the narrative on Sudhamma, has been dated by George Coedes to the first half of the eleventh century. ${ }^{54}$ Although Coedes does not tell us why he chose that particular date, I suspect it is because it fits the timing of Aniruddha's alleged conquest of Thatôn. Without a Mon Thatôn at that time, to which the refugees from Haripuñjaya could flee, the historicity of the epidemic itself would have come under question, as indeed it has more recently among Thai scholars, but for different reasons. ${ }^{55}$ It is entirely possible that this epidemic occurred earlier in the tenth century, as implied by the Câmadevivamsa's dating of it, and that might explain an early migration of Mon speakers into Lower Burma. But that in itself is not evidence of a Theravāda Buddhist Mon kingdom there prior to the decline of Pagán in the late thirteenth century. Besides, the first time Pagán-as Pukam, the same word used by Thais even today to refer to the city and kingdom-is mentioned in external epigraphy is in the Pô-Nagar Cham Inscription of 1050.56

Moreover, because the Câmadevivamsa states that the people who had 
fled to Sudhamma subsequently moved to Hamsavatī (Pegu), it suggests that Thatôn and Pegu were contemporaries or nearly so. Yet the first mention of Pegu in regional epigraphy by its formal, Pali name of Hamsavati is in Rāma Gāmheñ's Inscription of 129257; Burmese epigraphic evidence notes Pegu earlier, in $1266 .{ }^{58}$ If Pegu and Thatôn were generally contemporaneous, and if this link were not made later for purposes of unifying the origins of the Lower Burma Mon state, then the earliest that Suddhama might have existed as a city or town in Lower Burma is the late thirteenth century, exactly the same period when Rāmaññadesa also emerged in history.

The issue, therefore, is a problem of text-event contemporaneity. Even the original Cämadevivamsa, which has not survived as such, was not written until well after the decline of Pagán, while the date of the earliest extant copies from which the published version of 1920 is derived is not given by the translators of this edition. But considering the number of years that palm-leaf manuscripts can survive, it is unlikely that even the earliest extant copies are earlier than the eighteenth or nineteenth century. The Cāmadevivamsa, in short, is too late and problematic a source on which to base the historicity of Thatôn.

About a century later, if the dating is correct, another Northern Thai chronicle, the Jinakālamāli was said to have been written. It is dated variously between 1517/1518 and 1528, and attributed to Ratanapañna Thera, ${ }^{59} \mathrm{a}$ monk living in Chiang Mai, a major center in early Thai history. Although Sudhamma is mentioned here as well, and in the context of a cholera epidemic as in the Cämadevĩuamsa, the Jinakālamāli dates the episode to 657 $\mathrm{AD},{ }^{60}$ placing the event during the height of the Pyū period at Śrī Kṣetra, nearly 400 years before the city walls of Pagán were even built. Its account of the epidemic —assuming that it was the same one-is a bit different.

During his reign [one Kambala of Haripuñjaya who is perhaps the Kamala of the Canmadevivamsa], an epidemic of cholera raged for six years. And the citizens, not being able to survive there, all fled to the city of Sudhammanagara. Next, being harassed by the king of Punnagāma, all the Haripuñjaya citizens living in the city of Sudhammanagara left for the city of Hamsavati. When the epidemic of cholera had subsided, all of them returned to Haripuñjaya. ${ }^{61}$

There are several interesting pieces of information in this account as well. Because the Sudhammanagara in question is placed in the seventh century, it may have been a reference to Śrī Kṣetra, which also flourished at that time in Burma. This is linguistically possible, for Shorto has argued that the name Sudhammanagara could have been an etymon for Śrì Kṣe- 
tra, that is, the linguistic form from which another form is historically derived, so that the essential meaning of a word is seen in its origins. ${ }^{62}$ Moreover, this Sudhammanagara was mentioned in connection with a king of Puṇnagāma, which modern scholars have assumed is a reference to Pagán, ${ }^{63}$ but it is not. Puṇnagāma probably means the "city of the hermit" (or brahmin, although wrongly spelled) the name by which Śrì Kṣetra, not Pagán, was most commonly known, ${ }^{64}$ and therefore consistent with the date and etymon. Pugarāma, not Puṇnagāma, is the term for Pagán, and it is used only after the fifteenth century and largely during the eighteenth century. ${ }^{65}$

All this implies that Pyū Śrī Kṣetra in Central Burma may have been the Sudhammanagara mentioned in the Jinakālamāli, and therefore was not a reference to Thatôn of Lower Burma. This would suggest that the Sudhamma tradition originally might have been Pyū, and only later, via the Burmese speakers, became part of the Lower Burma tradition: Thatôn, after all, is the Burmese pronunciation of Sudhuim. Indeed, as we shall see below, late Mon texts also trace Thatôn's founding to two brothers who went there as hermits and hence the term Puṇnagāma, the "hermit city," for which, as noted, Śrī Kṣetra is best known. Once again, it suggests movement of culture, in this case origin myths, from north to south.

In the final analysis, like the Cāmadevivamsa, the Jinakālamālì was also written too late to prove that Sudhammanagara, if in Burma, was a contemporary of either Śrī Kṣetra or Pagán. But the text has many other problems, which will be discussed in Chapter Six, when I deal with the alleged conquest of Thatôn by Aniruddha.

Around the same time the Nidāna Árambhakathā, a Mon genealogy of kings, was said to have been compiled. Shorto wrote that the manuscript from which the published version is derived had a Pali colophon that suggests the main part, originally entitled "Rāmaññ'-uppatti-dīpaka," ${ }^{66}$ was composed by a monk after the end of Dhammazedi's line in 1538. But because later authors have added to it, the story actually goes up to at least 1661 and the reign of Pyi Min of the Second Ava Dynasty. Apparently the last page of the manuscript was missing, for Shorto did not provide the date of the extant copy that he used, a copy which can be found at the National Library in Bangkok and from which the published version of 1912 was taken.

The Nidāna opens with a very brief account of the history of Thatôn, omitting all mention of the "first" dynasty, as recorded in the Uppanna Sudhammawati-rājāwamsa-katha $\bar{a},{ }^{67}$ and enters into detail with the reign of King Manuha. The Nidāna is said by Shorto to have mentioned Thatôn in the context of Aniruddha's alleged conquest in 1057. If 1538 is in fact the 
original date when these earlier parts of the Nidanna were written, this then, is so far the earliest, nonepigraphic Mon text to mention Thatôn.

However, there are some problems here as well. First, Shorto concluded that the history of Thatôn in the Nidāna "is almost entirely legendary." 68 Second, by the time it was first written, over half a century had elapsed since the Kalyani Inscriptions were erected in which Thatôn was first mentioned. That means the Nidāna cannot be considered an independent source that proves the pre-Pagán existence of Thatôn. Moreover, before the mid-sixteenth century, the Mon Dynasty of Pegu, of which Dhammazedi was a part, was conquered by the Toungoo rulers, who established their capital at Pegu. From there they reunified Burma once more, particularly under Kings Tabinshwehti (1531-1550) and Bayinnaung (1551-1581). When the Nidāna gets to this part of the story, around 1540 and particularly Tabinshwehti's reign, the events are very precisely recorded in months and often days, ${ }^{69}$ suggesting that the author may have lived around that time.

Third, the published text in which the Nidāna appears ${ }^{70}$ was compiled and published only in 1910 or 1912, and its original provenance is unknown or at least has not been established to be earlier than the Nidāna's alleged compilation (1538), if correct. The same is true of the "Rāmaññ'-uppattidipaka," the original title Shorto said was the main part of the Nidāna. ${ }^{71}$

Finally, some parts of the late sections, or the latest version, of the Nidāna must have been compiled in the nineteenth century, for one of the miscellaneous traditions included in it is the story of Prince Asah's fight with the Indian, a story found in the Lik Smin Asah, a Mon romance not composed until 1825, to be discussed below. ${ }^{72}$ The Nidāna also includes the story of Wimala and Samala, the legendary founders of Pegu, two brothers whose ancestors were said to have come from India to live as hermits at Thatôn, and who subsequently founded that dynasty. Because the names of the brothers are said to be found in the dynastic lists of the Vijayanagara Dynasty of South India (fourteenth-seventeenth centuries AD), ${ }^{73}$ at least according to Phayre, prima facie, this version of the Thatôn/Pegu origins stories must also be late. That the story of Samala and Wimala is not mentioned in Dhammazedi's inscriptions regarding the origins of Pegu, his exemplary center, suggests that it might be a post-Dhammazedi legend added subsequently.

Shortly after the Nidāna was written, the Yazadarit Ayedawpon was composed by Bannya Dala, a Mon minister in the court of King Bayinnaung. The work was said to have been written in Burmese, although there is some controversy as to whether it was actually a translation of an earlier Mon work into Burmese or composed in Burmese from the start. In it, Thatôn receives about a sentence, which is also all but legendary. But unlike the Nidāna, the Yazadarit Ayedawpon has no known subsequent additions. As a 
result, it does not contain the later Price Asah, or the Samala and Wimala stories, confirming its editor's opinion that it was probably written during Bayinnaung's reign, well before the destruction of Pegu in 1599, only after which the Samala and Wimala story appears for the first time in Mon texts. ${ }^{75}$

The Yazadarit begins with the usual prophecies and stories about the arrival of the historical Buddha to Lower Burma. Like Dhammazedi's Kalyani Inscriptions, links are made to the ancient Buddhist city in north India, Kapilavastu, rather than to the much later Hindu kingdom of Vijayanagara in South India. As a result, links are also made to Tapussa and Bhallika, the famous merchant brothers of Buddha's India who were said to have enshrined eight strands of the Buddha's hair (or eight handfuls) in the Shwédagôn, rather than to Samala and Wimala.

Tapussa and Bhallika were said by the Yazadarit to have come from a place called Ukkalapa, Lower Burma's counterpart to Ussāla (or Orissa), after which both Pegu district and a municipality in north Yangôn is today named. After they had enshrined the Buddha's hair, the author absentmindedly has the brothers returning to Rajāgṛha in India, rather than to Lower Burma, the place they were said to have come from earlier in the text. ${ }^{76}$ That Tapussa and Ballikha, rather than Samala and Wimala, were the focus of attention shows that this text followed Dhammazedi's lead in the Kalyani Inscriptions as to the origins of Mon civilization in Lower Burma with Suvaṇnabhūmi and Thatôn and not the other, later version in which Hindu Vijayanagara was prominent.

The narrative in the Yazadarit differs from the Nidana in yet another way. ${ }^{77}$ It is more concerned with the local scene. That is, it is far more focused on the Muttama and Pegu regions of Lower Burma, where the first Mon Buddhist kingdom arose under Magadu, and with linking the founder of Pegu, not to Samala and Wimala as did later Mon texts, but to a Buddha prophesy about Muttama. This stated that an ogre (rakșa) named Sumani, living in the Muttama region, would become in time "lord of the white elephant." As prophesied by the Buddha, a succession of kings ensued. But no names or dates are given. The next paragraph jumps from the Buddha's time to King Narapatisithu of Pagán (1173-1210), who, the Yazadarit states, descended to Lower Burma in the twelfth century via his royal barge, called the cakra, on which he was touring the country. This is a local variation of the cakravartin's disk-spinning that conquers the world. It was only after Narapatisithu's tour that he founded the city called Motamo (Muttama). Leaving a myosa (lit. "town eater" or governor) there to govern it, Narapatisithu subsequently returned to Pagán. ${ }^{78}$

The ogre transformed its state of existence to that of a human at a place called Takowan and was named Magadu, who was, by all accounts, a histor- 
ical figure. Then, after a series of human and supernatural events that closely linked Magadu's rise as founder of the first Mon dynasty in Burma with Sukhodaya and the T'ai-he was said to have eloped with the daughter of the king of Sukhodaya-he returned to his birth place. ${ }^{79}$ From there he engineered a marriage alliance with the governor of Muttama appointed by Narapatisithu, eventually taking the city and adopting the regnal name of Waru, the Wareru of Burmese history, in 1281 AD. Subsequently he was said to have compiled a civil code (dhammathat), later called the Waru Dhammathat, popularly known as the Wagaru Dhammathat.$^{80}$ Detailed accounts of Magadu (Wagaru) that follow include a march on Tala (west of Yangôn) by Pagán's forces, led, it said correctly, by Yazathingyan, ${ }^{81}$ one of the famous so-called Shan Brothers. This event is independently confirmed by at least one contemporary Old Burmese inscription of Pagán, ${ }^{82}$ but it is unlikely that the author of the Yazadarit would have known of it or had access to it because he lived over 300 years later in a distant place. Pagán's march on Lower Burma gave Magadu the opportunity to take Pegu, at the time ruled by one Taraphya, after which Magadu put a minister in place who had been selected by the king of Sukhodaya.

Ultimately, the Buddha's prophecy regarding Wagaru's title of the "lord of the white elephant" comes true, as one is given to him by Sukhodaya's king, legitimating his rule as a cakravartin. Also during Wagaru's reign first mention is made of the contact between Muttama and Śri Lañkan Buddhism. ${ }^{83}$ Wagaru reportedly died in 1294; according to this account, he was killed while in the toilet by the sons of Taraphya, whom he had earlier overthrown. His death precipitated a struggle for the throne by his younger brothers, sons, and several others with the T'ai title Saw. Intrigues that directly involved troops from Sukhodaya and Chiang Mai and victories over and subsequent truces with the latter are all part of the story. Names of kings, queens, princes, and princesses are given, along with their exploits, until finally Pegu rises in ascendancy with Binnya $\mathrm{U}$, and Muttama becomes a vassal city. Only when Binnya U died in about 1385 did Yazadarit emerge, in whose name the book was written. From then until the end of the book, where his horoscope is given, the history is consumed with the drama between Ava's Mingaung I and Yazadarit, the former often overshadowing the latter.

Thus the "secular" history of Lower Burma even from the Burma Mon perspective in the Yazadarit actually begins with Burmese King Narapatisithu of Pagán and Magadu of Muttama. This is consistent with the general time frame and the way in which Lower Burma actually developed, particularly if only the contemporary archaeological, epigraphic, and Chinese records are used. This was also the time-the late twelfth and early thirteenth centuries-when most of the first towns and cities in Lower Burma 
began to appear in original epigraphs. That Magadu and his rise to power are linked to the T'ai polity of Sukhodaya rather than to South India is also supported by several contemporary T'ai inscriptions. ${ }^{84}$ The Yazadarit, in other words, is focused on the local, thirteenth-century origins of Pegu, whose historical links are to Pagán, Muttama, Sukhodaya, and Magadu, rather than to the origin stories that appeared much later, and whose links are to Vijayanagara and Wimala and Samala.

Thus the rise of the first Mon dynasty in Lower Burma as told by the earliest Mon history to have survived-especially one devoid of later interpolations - is more about Muttama than it is about Thatôn, more about Sukhodaya and Pagán than about Śrì Lañka and Vijayanagara. It is more about the region of which it was actually a part, a perspective that corresponds well with the best evidence we have. This rather straightforward historical nature of the work is not surprising, as the author was an experienced minister in the court of Bayinnaung, knowledgeable in warfare and administration, and known for his scholarship..$^{85}$

\section{Thatôn and Pegu in the Most Recent Domestic Sources}

Finally, we come to the most recent texts that describe the origins of the first putative capitals of the Mon in Lower Burma, Thatôn and Pegu, for by now they are inexorably linked. All originals of these texts postdate Dhammazedi's and Bayinnaung's dynasties by several centuries, including the later sections of the Nidāna, and as such are not contemporary evidence for the early presence of Thatôn or Pegu. They are discussed here for their importance in showing how recent some of the myths about Thatôn really are, and how insignificant the city was in the past, even to the Mon themselves.

We begin with U Kala's Mahayazawingyi whose section on Thatôn appears to be a summary of Mon legends concerning the founding of that city by two "Indian brothers," ${ }^{6}$ stories that are also contained in the seventeenth-century portions of the Nidāna, as shown above. The late eighteenth-century Burmese chronicle, the Myanma Yazawinthit (New history of Myanma or the Myanma people), which often quotes U Kala's work verbatim, also links Thatôn's origins to two Indian brothers who are probably Samala and Wimala of the Mon texts. ${ }^{87}$ Although from the time of U Kala's chronicle onward, Burmese sources more or less assume that Thatôn was the capital of the Mon in Lower Burma, in the Mon chronicles themselves, Thatôn's role in the history of the Mon people is still obscure and rarely mentioned.

Nearly contemporary with Twinthin's Yazawinthit is the late eighteenthcentury Slapat Rājawain Datow Smin Rón (History of kings). Sometimes hailed as the most important "chronicle" of the Mon, it was compiled by a 
monk probably a few decades after U Kala wrote his Mahayazawingyi. ${ }^{88}$ The title was actually given to the work by Père W. Schmidt, who first published it in German in 1906. C. O. Blagden subsequently began an English translation of Schmidt's work, but apparently never completed it, and that manuscript eventually passed on to Robert Halliday, an American missionary. Using both Schmidt's and Blagden's works, along with what he considered to be the best of the Mon manuscript versions, Halliday published his own English translation of it in the Journal of the Burma Research Society in 1923. ${ }^{89}$

The manuscript that Schmidt used is quite problematic. It was first sent to Blagden in 1892 by an H. L. Eales, who was an official engaged in the census of Burma of 1891. Eales, in turn, had obtained it from Maung Dut, "a Talaing" who was employed by the British Government as a revenue officer. The latter had acquired it from a Maung Meik of Saingdi, a village near Pegu, who said he had gotten it from his great-grandfather, one Bala Theikti, who had brought it back to Burma after a campaign against Thailand during Bodawpaya's reign. That original from Thailand was then said to have been given to a monk of Kokainggyi, but the son of Bala Theikti was said to have made a copy of it prior to the donation. The manuscript Blagden got from Eales was that son's copy, the original having been lost. ${ }^{90}$ Thus, apart from the circuitous route this most celebrated "history" of the Mon in Burma has taken, the manuscript was not even an indigenous Burma work but was taken from Thailand where it had been written by unknown hands.

In any case, the Slapat lists the standard seventeen generations of the "kings of Pegu," beginning with Samala and Wimala, who were said to have received the city of Pegu from Indra, while Thatôn's role in the development of Pegu and Lower Burma Mon civilization is conspicuously absent. The list ends with King Tissaraja, who is described as a "heretic turned to wrong-doing" who destroyed Buddha images and forbade worship of the Buddha. But a devout maiden refused to be swayed from the worship of the true religion, until finally victory was hers with the help of the Buddha. After that, Buddhism becomes dominant once again in the region with the "next" (actually former), Wareru (Magadu) Dynasty of Martaban.

The steadfast Buddhist maiden sounds as if Shin Saw Bu (1453-1472) were her model, while Tissaraja's age of heresy was probably an allusion to the period when the great Hindu Empire of Vijayanagara (fourteenth to seventeenth centuries) transgressed beyond its natural border, the Bay of Bengal, and exerted its influence over Lower Burma, ${ }^{91}$ either directly, via Arakan, or both. The "dark age" that was said to have preceded Wareru's Dynasty may well have been the sixteenth and early seventeenth centurieswhich actually followed Shin Saw Bu's dynasty in Lower Burma-when Pegu was burnt to the ground by Arakanese forces in 1599. Thereafter, eye- 
witnesses described Lower Burma as a depopulated wasteland without any central authority, ruled by individual warlords, the most famous of whom was the Portuguese adventurer Filipe de Brito y Nicote, also mentioned in the Slapat as a major character. ${ }^{92}$ The memory of such devastation probably inspired the eighteenth-century author with an appropriate Buddhist "dark age" metaphor. To him, a Buddhist monk, periods of disorder were invariably followed by periods of order, so that in his work, the period of order was linked to Wareru's late thirteenth-century dynasty. Thus, the Slapat's author seems to have projected backwards what was really a much later, and historical, period of "darkness" onto an unknown earlier time of darkness that preceded Wareru's period of order with the rise of Muttama.

It seems likely that the legend of Samala and Wimala as founders of Pegu entered Lower Burma only in the sixteenth and seventeenth centuries. Not only are the brothers said to be traceable to the lists of Chalukya kings and those of Vijayanagara, ${ }^{93}$ their legend is not mentioned in Shin Saw Bu's or Dhammazedi's inscriptions or the Yazadarit. Their tale cannot be found in the earlier Buddhist texts either, unlike Tapussa and Bhallika, Soṇa and Uttara, and the ogress of Suvaṇnabhūmi who devoured royal children. So it appears to be a post-Dhammazedi origins creation that emerged only after the fall of Pegu in 1599 with the rise of a new dynasty several decades later. ${ }^{94}$ With a new dynasty came a new origins myth, this one accurately revealing influences from South India, possibly via the Arakanese, who were, in fact, the ones to destroy the old dynasty. (The Hindu artifacts found in Lower Burma noted in previous chapters may actually have belonged to this period rather than the first millennium AD.) Not coincidentally, the Wimala and Samala myth also appears only in those portions of the Nidāna that were added towards the mid-seventeenth century; and as noted, they may also be the "Indian brothers" in U Kala's and Twinthin's eighteenth-century stories about Thatôn. ${ }^{95}$

In contrast, the origin myths of the Mon in Dhammazedi's inscriptions go back mainly to the stories found in the Sinhalese chronicles and the Pali Buddhist texts of Śrī Lañka. In Dhammazedi's account, the great Buddhist kings such as Aśoka, Parākramabāhu I, and Aniruddha are all important, while Soṇa and Uttara, Bhallika and Tapussa, and Sīrimāsoka are also central figures. Between Dhammazedi's reign and the destruction of Pegu the Yazadarit Ayedawpon appeared, which, after making a brief and perfunctory link to the Buddha, maintained its focus on the actual historical events, individuals, and places important to the region. All the other stories and characters in the Slapat that followed the Ayedawpon clearly belong to the period after Pegu was destroyed and Lower Burma had turned into a wilderness.

The next important Mon text, the Lik Smin Asah, written in 1825, 
retains the story of Wimala and Samala, but in altered form. Here, one of the brothers' offspring, Prince Asah, eventually fights against the Vijayanagara empire, ${ }^{96}$ which leads me to believe that the story was perhaps an allegory about the conflicting external influences that shaped Mon culture in Lower Burma. ${ }^{97}$ The story of the two brothers and their descendants in the Lik Smin Asah, is, therefore, one of the latest layers in the strata of Mon texts. At the bottom are the earlier Buddhist layers created by Dhammazedi, and in between them are the more secular historical strata by Bannya Dala and his Yazadarit. I have no doubt that others are in the process of being developed today that will stand on top of the Lik Smin Asah.

Sir Arthur Phayre's account regarding the origins of Thatôn and Pegu drew largely on these later (post-Dhammazedi) Lower Burma Mon sources. He traces Thatôn's origins in the story of the two sons ${ }^{98}$ of King Thiha (Lion) of Karanaka in Southeast India, who had come to dwell as hermits in "the savage land" of Lower Burma, founding the city of Thatôn. ${ }^{99}$ Supporting what we now know of the actual history of that area, Phayre writes: "Of the early history of Thathun, only vague tradition remains, though a list of fifty-nine kings, for the most part fabulous, who are said to have reigned there, is found in the Talaing chronicles." 100 Subsequently, according to Phayre, another set of brothers (but clearly not, for they are Wimala and Samala again), said to be sons of the reigning king of Thatôn, leave it to found Pegu. ${ }^{101}$ The elder of the two brothers, Samala, becomes the second king of the Mon at Pegu, succeeding one whose name was taken from a list of exemplary kings found in the Cülavamsa. ${ }^{102}$ Samala reigns for twelve years, the exact number that kings of ancient South India were theoretically expected to rule before relinquishing the throne and committing suicide. ${ }^{103}$ Subsequently, he is killed by his younger brother, Wimala, who takes over; although in another version, Wimala dies at the age of seven and is reborn in India as Gavampati. ${ }^{104}$ Since the origins of Thatôn and Pegu had been inexorably combined by the time of the manuscript Phayre used, the story of the two brothers had also been combined so that one is reborn as Gavampati, while the other is reborn as Sūriyakumā, our infamous Manuha. ${ }^{105}$

In sum, because the narrative concerning the origins of Pegu and Thatôn is a multilayered text derived from different periods of Lower Burma's history, in which time, place, events, and individuals had been conflated for purposes of legitimacy, it often seems contradictory, redundant, anachronistic, and confusing. The concept of reincarnation allowed the simultaneous presence of multiple personalities and locations, as well as anachronistic, ahistorical, and redundant scenarios. Everything now fits everywhere, much in the same way Dhammazedi, in his inscriptions, col- 
lapsed Buddhist India's chronologies, geographies, and genealogies into Lower Burma's, and Shorto, in his interpretation of the Gavampati tradition, did much the same thing. Some of these conflated texts are then conflated even further by the time they appear in the twentieth century.

\section{Conclusion}

Traditions in Burma are seldom discarded entirely; they are retained and added to. All the different origins stories of Thatôn and Pegu finally become part of the Lower Burma Mon tradition, resulting in a prevailing (even if confusing), multilayered product. This tradition, in turn, was incorporated into the broader Burmese narratives, so that the result was an integrative, not a contested narrative. ${ }^{106} \mathrm{Had}$ they been contested stories, the final product - that is, the topmost layer representing the latest additionwould likely have expunged rather than included the earlier, especially contradictory material. Instead, the nineteenth-century Burmese texts representing the "winners" in the struggle for power in precolonial Burma did not delete, but retained the legends and history of the Mon people, as well as those of the Arakanese and Shan, as shown by U Kala's, Twinthin's, and the Hmannan's treatment of these people and the accounts of themselves. Lower Burma's Mon narrative was even incorporated into the mid-nineteenth-century Pali chronicle, the Sāsanavaṃsa, written in Upper Burma and meant to represent Upper, not Lower Burma orthodoxy. ${ }^{107}$ By the midto late nineteenth century, the earlier Lower Burma stories dealing with Sona and Uttara, Bhallika and Tapussa, and the later ones concerning Wimala and Samala ${ }^{108}$ had become part of a larger, kingdom-wide narrative, even if initially they had belonged and were meaningful only to the Mon of Lower Burma.

In this process of narrative integration, certain stock characters or markers played crucial roles. Most of these links in Burma's indigenous history begin with a set of two brothers, ${ }^{109}$ or sometimes male friends, who act as founders of sacred cities or religious sites, at the beginning of which an actual historical "conjuncture" in Fernand Braudel's sense, seems to have occurred. Bridging the needed gaps further are Buddhist deities such as Gavampati who act as liaisons between past and present, old and new, indigenous and foreign, interior and coast, change and continuity.

What is striking in these stratified origins narratives is that Thatôn is almost an afterthought. It is not even mentioned in any original domestic source until the erection of King Dhammazedi's inscriptions. Even when it does appear in original epigraphy, it is not in a context of celebration but of embarrassment, for the religion introduced to Thatôn by the Buddha, 
restored by Gavampati, and renewed by Soṇa and Uttara had been permitted to decay by its king, Sūriyakumā (our Manuha), who was hatched, of course, from "the other" (bad) egg. ${ }^{110}$

Only in 1486 did someone-perhaps Dhammazedi, we do not knowerect three more inscriptions that provided Thatôn with a more sanitized record and genealogy in the person of Gavampati (hatched from the "good egg") and Sīrimāsoka, both of whom were responsible for the personal visit to Thatôn by the Buddha. Thus it was only after Dhammazedi's first indictment of Thatôn with Manohor in his Kalyani Inscriptions that an attempt was made a decade later to rectify and perhaps rescue the situation by providing the city with a better record. But it was too late, for Thatôn had already been derided publicly at the "national" level.

The Mon chronicles that appeared after Dhammazedi's inscriptions ignored the 1486 attempt to give it a bit more credibility. Thatôn is barely mentioned in the Nidāna or the Yazadarit Ayedawpon, while the first center of Mon culture in Lower Burma is not Thatôn but Martaban and Pegu. And in the eighteenth-century texts, the "Gavampati" and Slapat, Thatôn was not mentioned, nor did it play even a minor role in the history of the Mon in Lower Burma. Robert Halliday wrote in 1913 that of the three great Mon capitals-Thatôn, Martaban, and Pegu-only the last "lives in the memory of the bulk of present-day Talaings as the great city of their kings." 111

But that sentiment was not shared by colonial scholars, as became apparent in the first few decades of the twentieth century when the idea of Thatôn as a "national tragedy" became an issue in Burma's historiography. Only then was Thatôn transformed into both the Camelot of the Burma Mon and the ultimate symbol of their defeat, their Alamo. This new sentiment was a late, external perspective, the direct result of colonial scholarship on the Mon.

Similarly, none of the Burma Mon texts looked east to what many colonial and other modern scholars have considered to be the homeland of the Mon: Dvāravatī. Rather, their gaze was west to South Asia: Śrī Lañka earlier, and later, South India's empire of Vijayanagara and the Talingas. Thus, while modern western officials and scholars were nostalgically looking towards Dvāravatī on behalf of the Burma Mon; the Burma Mon themselves were gazing in the opposite direction, towards South Asia.

In fact, not a single Mon inscription of Burma, from the eleventh-century stones of King Kyanzittha's to those of the fifteenth century belonging to King Dhammazedi and later, attributes the origins of the Burma Mon, either as allegory or history, to Dvāravatī or Haripuñjaya; neither place is even mentioned. This suggests that as early as the Pagán Dynasty the Mon 
of Burma had apparently already forgotten from whence they came, until colonial scholarship rediscovered that history and told them. ${ }^{112}$

But colonial scholarship also turned ethnicity into an issue of major political, social, and economic importance and divisiveness, so that the cultural differences between Mon and Burman that had rarely been that important an issue in the course of their everyday lives, now became a central adversarial theme in the historiography of Thatôn. The Thatôn tradition, once of little importance to the Mon, had now become a cause celebre of their nationalism, endorsed and encouraged by their colonial masters.

That, in turn, shaped the interpretation of the multilayered and integrative narrative of Mon Lower Burma, so that the new, modern Thatôn focus became the only "orthodox" one. Heretofore, as long as religious legitimation was the primary issue of concern in society-and it had beenand both Burman and Mon sought legitimation in the same religious tradition-and they did-the cultural narrative was inclusive rather than exclusive, integrative rather than contested. But in the twentieth century ethnicity became a contested political, and hence economic and social, issue at a national level. That took both Mon and Burman out of their previous more localized historical context and placed them in a much broader, international modern, adversarial one. It was only then that the inclusive narrative turned into a nationally contested one. But this was the modern world reinterpreting the local narrative to fit its own purposes.

Once ethnic nationalism and nationhood became the most important issues, reified ethnicity, the foundations on which the majority of today's modern nations are built in the first place, reared its head. In this political, and also historiographic, struggle, the alleged conquest of Thatôn by King Aniruddha became a central theme, the topic of the next two chapters. 